\title{
Bacterioplankton RNA, DNA, protein content and relationships to rates of thymidine and leucine incorporation
}

\author{
Wade H. Jeffrey ${ }^{1, *}$, Robin Von Haven ${ }^{1}$, Matthew P. Hoch ${ }^{2, * *}$, Richard B. Coffin ${ }^{3}$ \\ ${ }^{1}$ Center for Environmental Diagnostics and Bioremediation, University of West Florida, Pensacola, Florida 32514, USA \\ ${ }^{2}$ Department of Oceanography, Texas A \& M University, College Station, Texas 77843, USA \\ ${ }^{3}$ Gulf Breeze Environmental Research Laboratory, United States Environmental Protection Agency, Gulf Breeze, \\ Florida 32561, USA
}

\begin{abstract}
Bacterial macromolecules have often been used successfully as estimates of bacterial biomass in environmental samples. Less is known about the relationship between macromolecular content and rates of growth and activity. The ratio of RNA to DNA in bacteria has long been thought to be proportional to levels of metabolic activity and growth. We have used the nucleic acid fluorochrome thiazole orange combined with specific nuclease digestions to determine RNA:DNA ratios and compared these data to more standard measures of bacterial growth and activity. More than 100 samples from a wide variety of estuarine and marine environments were examined and the average RNA, DNA, and protein content per bacterial cell was found to be $9.44 \pm 6.25 \mathrm{fg}, 5.75 \pm 2.35 \mathrm{fg}$, and $29.29 \pm 11.57 \mathrm{fg}$. respectively. Initial experiments demonstrated a strong correlation of RNA:DNA ratios with growth rates for a laboratory organism. We then compared RNA:DNA ratios to cell specific rates of ${ }^{3} \mathrm{H}$-thymidine and ${ }^{14} \mathrm{C}$-leucine incorporation as estimates of growth rates for naturally occurring bacterioplankton communities in whole water and the $<0.8 \mu \mathrm{m}$ size fraction in estuarine and coastal waters in the Northern Gulf of Mexico. Nucleic acid ratios were generally very low in the natural communities, usually below those determined for late stationary phase pure cultures. No significant or consistent relationship was observed between RNA:DNA ratios and rates of ${ }^{3} \mathrm{H}$-thymidine and ${ }^{14} \mathrm{C}$-leucine incorporation in naturally occurring bacterioplankton communities. No relationship could be ascertained whether compared against location or water temperature. Thymidine incorporation rates were found to be completely independent of cellular protein content while leucine incorporation rates were more related to protein content. Our data suggest that while RNA, DNA, and protein content are strongly correlated with bacterial numbers in our environmental samples, the low metabolic activity and the heterogeneous composition of bacterioplankton communities may preclude the use of these parameters as biochemical indicators of activity in the environment.
\end{abstract}

KEY WORDS: RNA:DNA ratios · Thymidine incorporation · Leucine incorporation

\section{INTRODUCTION}

Bacterial biomass has most often been measured with epifluorescence direct counts (Hobbie et al. 1977, Porter \& Feig 1980) and occasionally by macromolecular components such as DNA (Paul \& Carlson 1984,

·E-mail: jeffrey@gulf.net

-C Current address: Biology Department, Malaspina University-College, 9005 th Street, Nanaimo, British Columbia, Canada V9R 5S5
Paul et al. 1985), protein (Simon \& Azam 1989), ATP (Karl 1993), and lipids (Findley et al. 1989). Methods to measure bacterial activity and productivity have not been without controversy and have most often included radiotracer assays using assimilation of ${ }^{3} \mathrm{H}$ thymidine as an estimator of DNA synthesis (Fuhrman \& Azam 1982), ${ }^{3} \mathrm{H}$-adenine as an estimator of DNA. and RNA synthesis (Karl 1982), ${ }^{3} \mathrm{H}$-uridine to estimate RNA synthesis (LaRock et al. 1979), and ${ }^{14} \mathrm{C}$-leucine incorporation to estimate protein synthesis (Kirchman 
et al. 1985). Questions about the reliability of the different radiotracer methods has led to the testing of other methods by which bacterial productivity may be estimated. Biochemical indicators of metabolic activity have been more scarce and have included adenylate energy charge (Karl \& Holm-Hansen 1978) and ATP:DNA ratios (Jeffrey \& Paul 1986a, b). The ratio of RNA to DNA in bacteria has long been thought to be proportional to levels of metabolic activity and growth based on several studies with enteric bacterial strains of Escherichia coli and Salmonella typhimurium (Neidhardt \& Magasanik 1959, Kjeldgaard \& Kurland 1963, Maaløe \& Kjeldgaard 1966, Rosset et al. 1966) which often used growth rates orders of magnitude faster than those measured in the environment. RNA:DNA ratios have been used as biochemical indicators of growth in a wide variety of marine organisms including phytoplankton (Thoreson et al. 1983, Dortch et al. 1985, Berdalet \& Dortch 1991), invertebrates (Sutcliffe 1970), fish (Buckley \& Lough 1987. Bulow 1987), and, more recently, bacteria (Mordy \& Carlson 1991, Kemp et al. 1993, Kerkof \& Ward 1993). Most studies with marine bacteria have analyzed growth under laboratory manipulated conditions (Kemp et al. 1993, Kerkhof \& Ward 1993) with few analyses of indigenous bacterial populations (Mordy \& Carlson 1991, Lee \& Kemp 1994). While RNA:DNA ratios have generated interest in recent years, total protein content and its relationship to rates of bacterial activity and growth has received minimal investigation. We have used the nucleic acid fluorochrome thiazole orange (Berdalet \& Dortch 1991) combined with RNAase digestions to determine RNA:DNA ratios in a wide variety of oceanic and estuarine samples and compared these data with more commonly used measures of bacterial activity and productivity, ${ }^{3} \mathrm{H}$-thymidine and ${ }^{14} \mathrm{C}$-leucine incorporation. In addition, we have determined protein concentrations in a variety of natural bacterioplankton samples and examined whether protein content is related to bacterial growth rates.

\section{MATERIALS AND METHODS}

Sampling collection. The location of sampling sites is depicted in Fig 1 Water samples were collected during 2 cruises in the Northern Gulf of Mexico aboard the RV 'Gyre' during 2-6 October 1992 and the OSV 'Peter W. Anderson' during 21-26 May 1993. Surface water samples were collected from coastal waters along the Florida, USA, panhandle during 2 cruises aboard the RV 'Bellows' 11-15 May 1992 and 3-6 May 1993. A 48 h diel study was conducted in Santa Rosa Sound on 29-30 September 1993. Samples were also

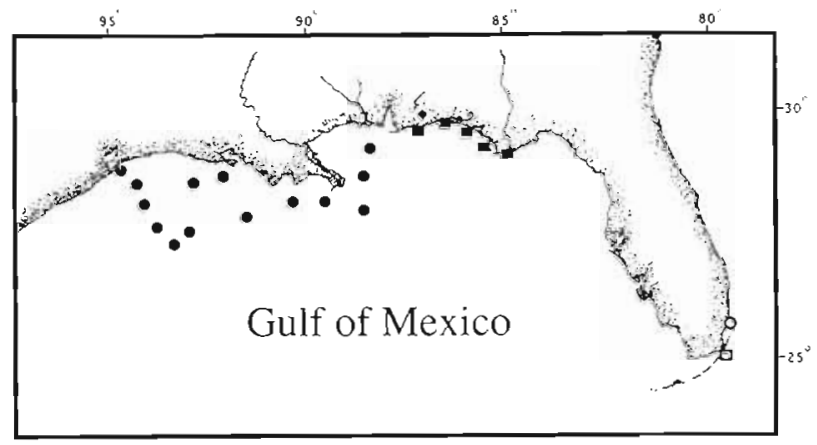

Fig. 1 Locations of water samples collected during a cruise aboard the (-) RV 'Gyre' during 2-6 October 1992 and the OSV 'Peter W. Anderson' 21-26 May 1993, and aboard the (-) RV 'Bellows' 11-15 May 1992 and 3-6 May 1993. (•) $48 \mathrm{~h}$ diel study conducted in Santa Rosa Sound 29-30 September 1993. (o) Samples collected in transects from the Virginia Key sewage outfall aboard the OSV 'Peter W. Anderson' 13 and 14 March 1993. (a) Samples collecter from roral surface mucrolayers off Key Largo, Florida, 28 June to 12 July 1992

collected from coastal waters adjacent to Miami, Florida, during 13 and 14 March 1993 while aboard OSV 'Peter W. Anderson' and from coral surface microlayers off Key Largo, Florida, 28 June to 12 July 1992.

Samples for nucleic acid determinations were collected as follows. Whole water samples (sextuplet) of 100 to $500 \mathrm{ml}$ were immediately filtered through $0.22 \mu \mathrm{m}$ pore-size Millipore (Bedford, MA, USA) GS filters which were then rolled in $2 \mathrm{ml}$ micro-centrifuge tubes (particle side inward) and frozen in dry ice after the addition of $1 \mathrm{ml}$ Tris- $\mathrm{Ca}^{++}$buffer $(0.1 \mathrm{M} \mathrm{NaCl}, 0.1 \mathrm{M}$

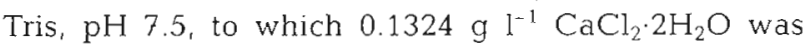
added after autoclaving; Berdalet $\&$ Dortch 1991). To remove organisms larger than bacteria, water was passed through a $10 \mu \mathrm{m}$ pore-size cartridge prefilter (MSI, Westboro, MA, USA) followed by a $0.8 \mu \mathrm{m}$ poresize cartridge filter (Nuclepore, Pleasanton, CA, USA). Samples were then filtered and frozen as described for whole water samples. Samples for protein determinations in the $<0.8 \mu \mathrm{m}$ fraction were collected on $0.22 \mu \mathrm{m}$ pore-size Millipore GV membranes and all samples were stored on either dry ice or at $-70^{\circ} \mathrm{C}$ until analysis.

Fluorometric quantification of RNA and DNA. Nucleic acids were determined by combining extraction via sonication methods described by paui \& Myers (1982) with the use of the fluorochrome thiazole orange which reacts with both DNA and RNA (Berdalet \& Dortch 1991). Thiazole orange (Becton Dickenson, San Jose, CA) was maintained as a $4.33 \mathrm{M}$ stock solution in methanol and added to samples at a final concentration of $3.43 \times 10^{-7} \mathrm{M}$. Samples were allowed to thaw on ice and the filter and Tris- $\mathrm{Ca}^{++}$ were transferred to a $20 \mathrm{ml}$ snap cap vial. An additional $2 \mathrm{ml}$ of buffer and Triton $\mathrm{x}-100$ (final concentration $0.05 \%$ ) were added. Samples were sonicated on 
ice for $40 \mathrm{~s}$ using a ca $1.9 \mathrm{~cm}(0.75$ inch) tip on a Tekmar Sonic Disrupter model TM 600 set at 10\% max output. Two $\mathrm{ml}$ of the buffer was microcentrifuged at $10000 \mathrm{rpm}(8000 \times 9)$ in an Eppendorf model 5402 centrifuge for $10 \mathrm{~min}$ at $4^{\circ} \mathrm{C}$ and the clarified supernatant divided into 3 subsamples. For total nucleic acid fluorescence, 1 aliquot was brought to a final volume of $2 \mathrm{ml}$ with Tris- $\mathrm{Ca}^{++}$and $1 \mathrm{ml}$ of $1.03 \mu \mathrm{M}$ thiazole orange working solution added. A second subsample was treated with RNAase (Type III A, Sigma Chemical Co, St. Louis, MO, USA) by adding $50 \mu l$ of a $1 \mathrm{mg} \mathrm{m}^{-1}$ stock solution to the sample and incubating at $37^{\circ} \mathrm{C}$ for $10 \mathrm{~min}$. These samples were then brought to a final volume of $2 \mathrm{ml}$ with Tris- $\mathrm{Ca}^{++}$and $1 \mathrm{ml}$ working solution of thiazole orange added. Fluorescence was determined on a Perkin Elmer LC50 spectrofluorometer with excitation $\left(E_{\mathrm{x}}\right)$ and emission $\left(E_{\mathrm{m}}\right)$ wavelengths of 511 and 533 , respectively. DNA content was determined in a third subsample using the DNA specific fluorochrome Hoechst 33258 (Calbiochem, La Jolla, CA) as previously described (Paul \& Myers 1982) using a Turner model 112 filter fluorometer $\left(E_{\mathrm{x}}=320-390 \mathrm{~nm}_{i} E_{\mathrm{m}}=430-490 \mathrm{~nm}\right)$. Unknowns were compared against standard curves generated using calf thymus DNA and Escherichia coli tRNA (Paul \& Myers 1982, Berdalet \& Dortch 1991). Linear regression of typical standard curves resulted in $\mathrm{r}^{2} \geq 0.99$ (data not shown).

Protein concentrations. Protein content of bacteria size particles was measured using the bicinchoninic acid (BCA) assay (Smith et al. 1985). Bacteria size particles $(<0.8 \mu \mathrm{m})$ were collected on Millipore type GV membranes ( $0.22 \mu \mathrm{m}$ pore size), and the membrane plus particles was stored in a $1.5 \mathrm{ml}$ screw-cap tube with $\mathrm{O}$-ring at $-70^{\circ} \mathrm{C}$. Protein was extracted by adding $1 \mathrm{ml}$ of $1 \%$ sodium dodecyl sulphate (SDS) and heating for $10 \mathrm{~min}$ at $100^{\circ} \mathrm{C}$. The extract with membrane was centrifuged at $14000 \times g$ for $10 \mathrm{~min}$ at room temperature, and an aliquot of the supernatant to be assayed was transferred to a fresh tube. Assay reagents and protocol were according to the Pierce (Rockford, IL, USA) kit \#23235. Bovine serum albumin (BSA) diluted in $1 \%$ SDS was used as standard. Concentration was calculated from the linear regression equation derived from standard treated as samples (i.e. membranes were added and then tubes were heated). Therefore, standards curves used here accounted for both the filter background and any loss of protein to the filter. The later problem was minimal because Millipore GV membranes are low protein binding. Slopes of standard curves for standards with or without a GV membrane and heating were not significantly different ( $t$ test, $\mathrm{p}<0.01$ ).

${ }^{3} \mathrm{H}$-thymidine and ${ }^{14} \mathrm{C}$-leucine incorporation. The method for ${ }^{3} \mathrm{H}$-thymidine and ${ }^{14} \mathrm{C}$-leucine incorpora- tion into the total macromolecule fraction has been previously described (Chin-Leo \& Kirchman 1988). ${ }^{3} \mathrm{H}$ thymidine was added to triplicate samples to a final concentration of $10 \mathrm{nM}$ while ${ }^{14} \mathrm{C}$-leucine was added to a final concentration of $20 \mathrm{nM}$. All incubations were limited to 30 to $60 \mathrm{~min}$. Bacterial numbers were determined by epifluorescence direct counts of 4',6diamidino-2-phenylindole (DAPI) stained samples by the method of Porter \& Feig (1980).

RNA:DNA in culture. To confirm that the method could detect changes in RNA:DNA ratios in bacteria growing at different rates, Escherichia coli JM109 was followed through a typical growth curve and sampled for RNA:DNA ratios. Cells were grown overnight in Luria-Bertani (LB) medium (Sambrook et al. 1989) and a $5 \%$ inoculum added to fresh medium. Absorbance at $550 \mathrm{~nm}$ was used to monitor cell density. Cells were collected for RNA:DNA ratios at lag, mid-log, late-log, and stationary phases of growth. RNA:DNA ratios were determined as described above

\section{RESULTS}

\section{Fluorometric determination of RNA:DNA ratios}

Initial experiments indicated that sonication of the filter containing the cell sample for $40 \mathrm{~s}$ using a ca $1.9 \mathrm{~cm}(0.75$ inch $)$ tip on the available sonicator (Tekmar Sonic Disrupter model TM 600 set at $10 \%$ max, output) yielded maximal recovery of both RNA and DNA (data not shown). Preliminary experiments indicated that a thiazole orange final concentration of $3.43 \times 10^{-7} \mathrm{M}$ gave linear fluorescence yields with both RNA and DNA standards between 0 and $2 \mu \mathrm{g}$. The fluorescence yield between Hoechst 33258 and DNA has been described previously (Paul \& Myers 1982), and we did not deviate from the methodology described in that study.

Thiazole orange fluorescence can be used to determine both DNA and RNA content (Berdalet \& Dortch 1991). There was no significant difference between DNA content determined using thiazole orange and Hoechst 33258 ( $p<0.001$ ). We opted, however, to use Hoechst 33258 for DNA determinations since it would allow direct comparison with earlier studies of DNA content in marine bacterioplankton (Paul \& Carlson 1984, Paul et al. 1985). To determine RNA content we opted to use RNAase treatments instead of DNAase treatments because the RNAase reactions were more rapid and did not require the addition of $\mathrm{Mg}^{++}$which appeared to alter fluorescence with thiazole orange. A $10 \mathrm{~min}$ incubation was sufficient for complete RNAase digestion and resulted in no loss of 


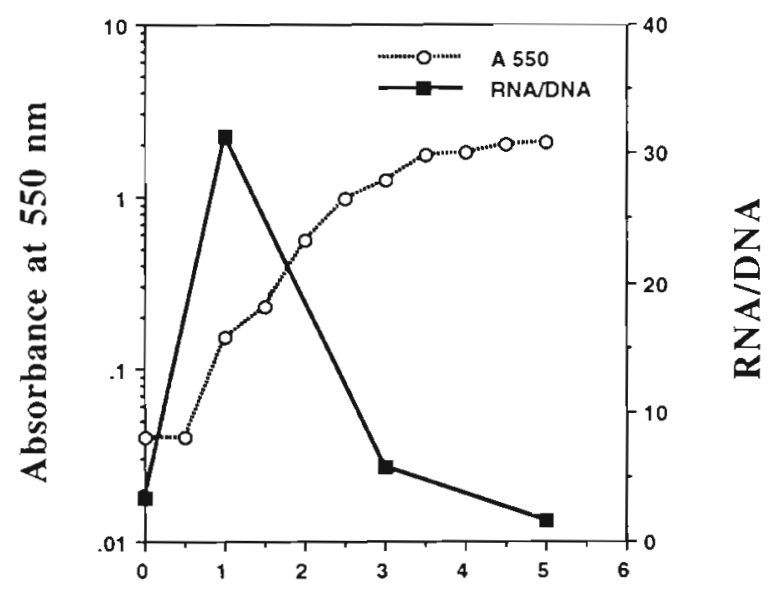

Time (h)

Fig. 2. RNA/DNA ratios of Escherichia coli strain JM109 during a growth curve. A sharp increase in the RNA:DNA ralio was seen in mid-log phase followed by a rapid decline toward stationary phase

DNA fluorescence (data not shown), RNA content was determined from the amount of fluorescence lost after RNAase digestion. All samples were conducted in 3 to 6 replicates. The mean coefficient of variation for all samples $(\mathrm{n}=180)$ was $13.61 \pm 8.24$ for $\mathrm{RNA}$, $7.11 \pm 5.72$ for DNA, and $17.13 \pm 12.77$ for RNA:DNA ratios.

\section{RNA:DNA ratios in bacterial culture}

RNA:DNA ratios measured in Escherichia coli during a growth curve are presented in Fig. 2. The methods were able to detect distinct changes in RNA:DNA ratios in this bacterial culture sampled under widely different growth rates. RNA:DNA ratios were observed to be proportional to growth rate in $E$. coli grown in the lab. A sharp increase was seen in the ratio of RNA:DNA during mid-log phase (maximal growth rate) followed by a rapid decline toward the onset of stationary phase and into late stationary phase.

\section{Macromolecular content and ${ }^{3} \mathrm{H}$-thymidine and ${ }^{14} \mathrm{C}$-leucine incorporation rates}

Comparison of cellular rates of ${ }^{3} \mathrm{H}$-thymidine and ${ }^{14} \mathrm{C}$-leucine incorporation with RNA:DNA ratios in
Fig. 3. Comparison of RNA/ DNA ratios with ${ }^{3} \mathrm{H}$-thymidine $(T d R)$ and ${ }^{14} \mathrm{C}$-leucine incorporation. Symbols represent different sampling locations: (o) RV 'Bellows', May 1992; (•) RV 'Gyre', October 1992; (ㅁ) RV 'Bellows', May 1993; ( $\Delta$ ) Miami, March 1993; (n) OSV 'Peter W. Anderson', Gulf of Mexico, May 1993; (4) Key Largo, coral Reefs. Cellular rates of (A) ${ }^{3} \mathrm{H}$-thymidine incorporation and (B) ${ }^{17} \mathrm{C}$-leucine incorporation in whole water fractions. Cellular rates of (C) ${ }^{3} \mathrm{H}$-thymidne incorporation and (D) ${ }^{14} \mathrm{C}$-leucine incorporation in the $<0.8 \mu \mathrm{m}$ fraction. $r^{2}$ values were determined by linear correlation
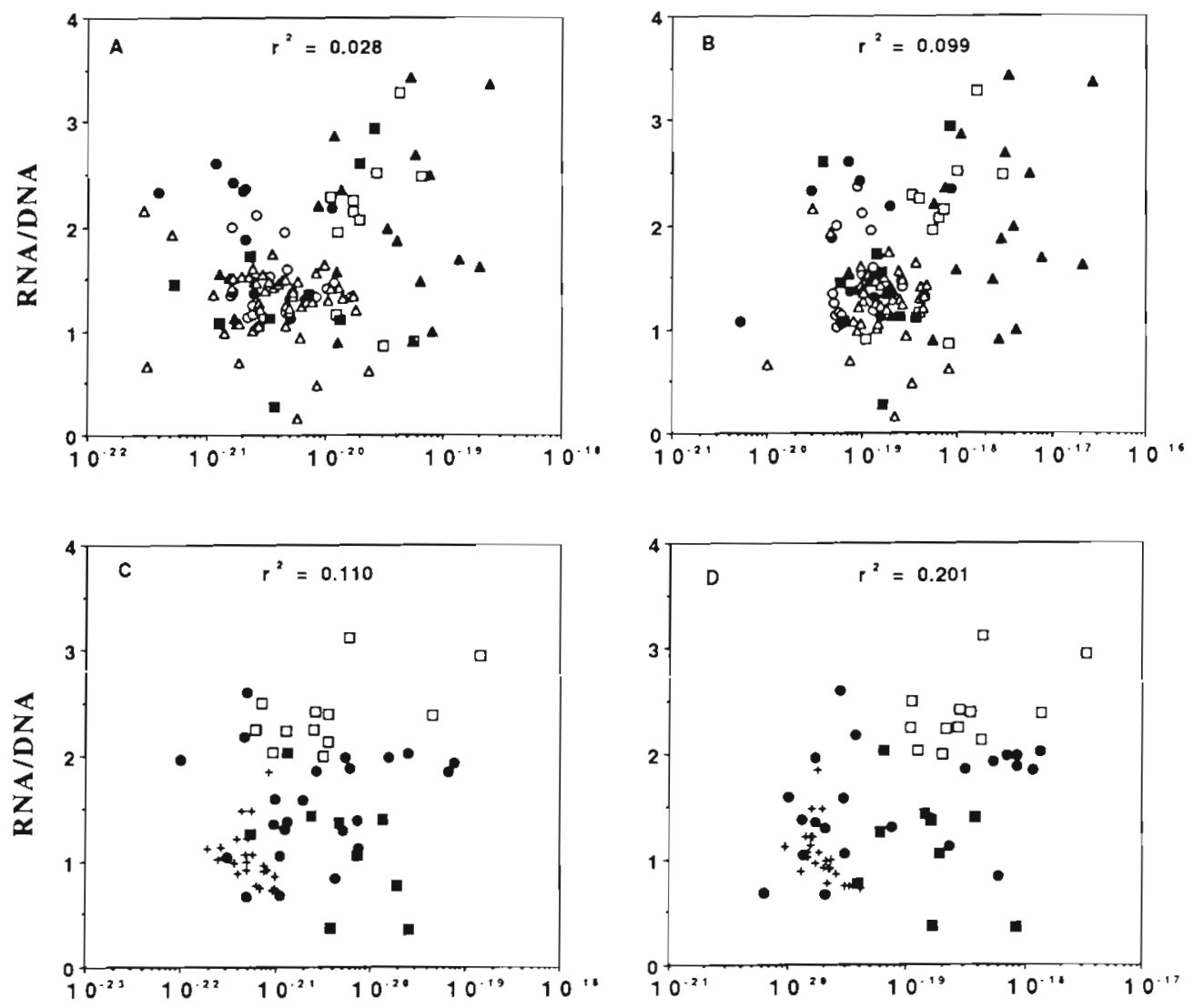

Moles TdR Incorp/Cell/h

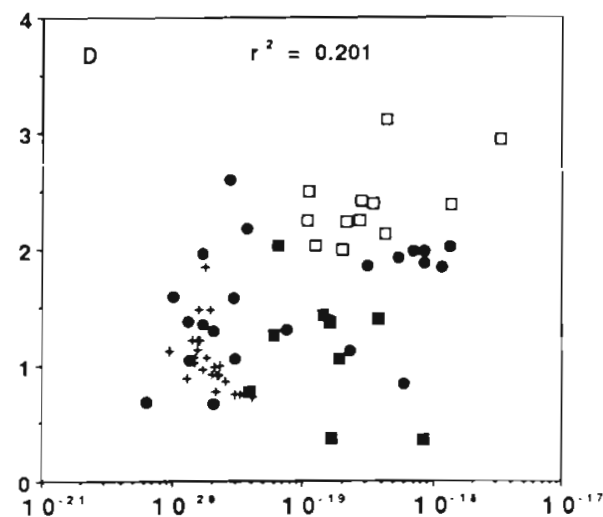

Moles Leucine Incorp/Cell/h 
whole water and the $<0.8 \mu \mathrm{m}$ fraction are presented in Fig. 3. A total of 120 whole water and 90 size-fractioned samples were analyzed. The wide variety of environments sampled provided for a large range (greater than 3 orders of magnitude) in rates of thymidine and leucine incorporation. RNA:DNA ratios generally ranged between 0.5 and 3.5 (average $1.54 \pm$ 0.58 ) for the whole water samples (Fig. 3A, B). No significant relationship was observed between RNA:DNA ratios and either radiotracer method. This absence of correlation was observed when data were grouped together as 1 data set or separated by research cruise location.

In certain environments, significant proportions of the total cellular nucleic acid pool might be due to micro-eukaryotes which have not been documented to incorporate significant amounts of ${ }^{3} \mathrm{H}$-thymidine and ${ }^{14} \mathrm{C}$-leucine added at $\mathrm{nM}$ concentrations. To ensure that the majority of micro-eukaryotes were removed, water samples were passed through a $0.8 \mu \mathrm{m}$ pore-size filter. The percentage of the total particulate DNA in the $<0.8 \mu \mathrm{m}$ size fraction ranged from approximately $90 \%$ in oligotrophic Gulf of Mexico waters to approximately $20 \%$ in some estuarine samples (Jeffrey unpubl. results). Again, thymidine and leucine incorporation rates ranged over several orders of magnitude while RNA:DNA ratios ranged between 0.5 and 3 with an average of $1.42 \pm 0.57$. Results from the $<0.8 \mu \mathrm{m}$ (presumably bacteria) size fraction are presented in Fig. 3C, D. The correlation coefficients for both thymidine and leucine incorporation and RNA:DNA ratios in the size fractioned samples were again very low (Fig. 3C, D).

Cellular protein content in the $<0.8 \mu \mathrm{m}$ fraction was significantly correlated $(p<0.05)$ with both cellular DNA content $\left(r^{2}=0.55\right)$ and RNA content $\left(r^{2}=0.72\right)$ but less correlated to activity measures of ${ }^{3} \mathrm{H}$-thymidine $\left(r^{2}=0.08\right)$ and ${ }^{14} \mathrm{C}$-leucine $\left(\mathrm{r}^{2}=0.49\right)$ incorporation.

\section{RNA, DNA, and protein content in environmental samples}

Macromolecular content in bacterial cells in the $<0.8 \mu \mathrm{m}$ size fraction was determined. The average bacterial DNA content for all samples ( $n=126$ ) was $5.75 \pm 2.35 \mathrm{fg}$ while RNA content averaged $9.44 \pm 6.25 \mathrm{fg} \mathrm{cell}^{-1}(\mathrm{n}=90)$, and protein content averaged $29.28 \pm 11.57 \mathrm{fg} \mathrm{cell}^{-1}(\mathrm{n}=103)$. The relationship between DNA $I^{-1}$, RNA $\mathrm{I}^{-1}$, and protein $\mathrm{I}^{-1}$ and bacterial numbers in the $<0.8 \mu \mathrm{m}$ fraction for all locations is presented in Fig. 4. Each macromolecule was significantly correlated with bacterial cell numbers.
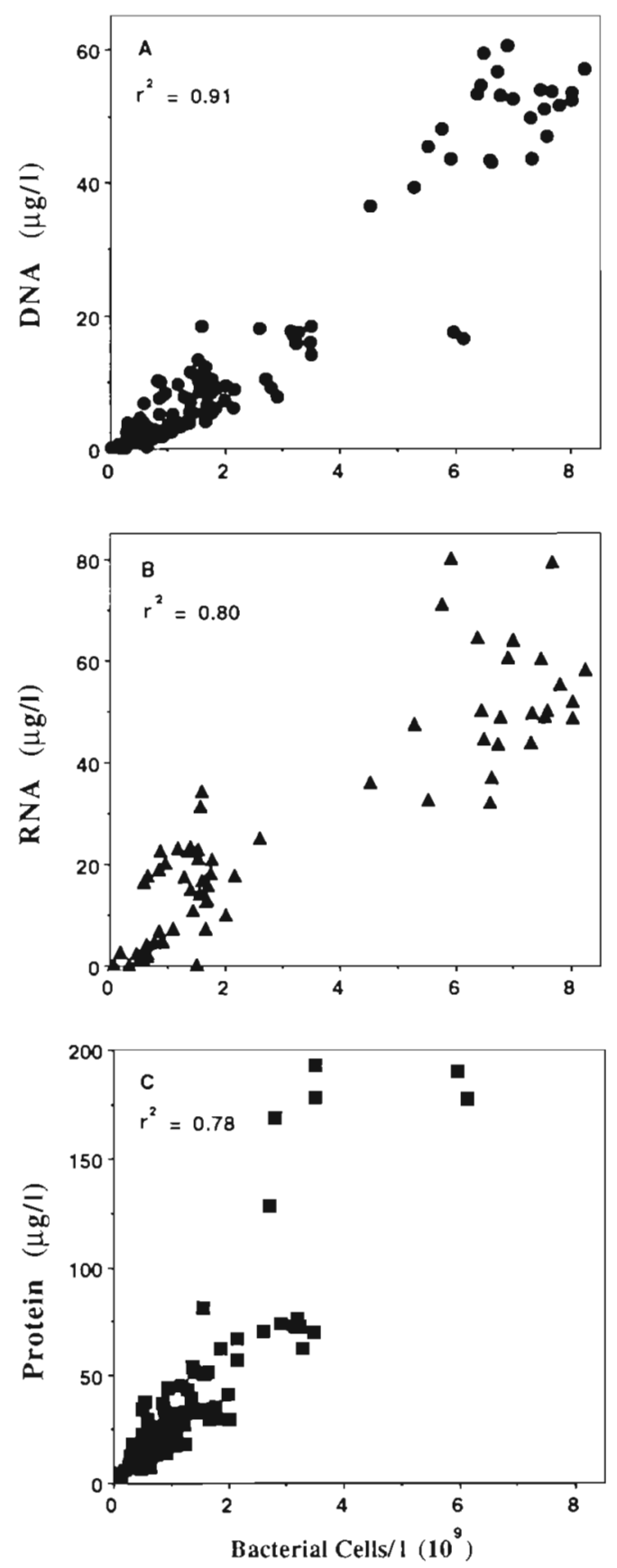

Fig. 4. Bacterial numbers and (A) DNA, (B) RNA, and (C) protein concentrations in the $<0.8 \mu \mathrm{m}$ size fraction

\section{DISCUSSION}

Fluorometric quantification of nucleic acids has been conducted for several years in a wide variety of sample types. Hoechst 33258 has been used extensively to quantify bacterial DNA content in marine ecosystems (Paul \& Myers 1982, Paul \& Carlson 1984, Paul et al. 1985, Boehme et al. 1993). The vast majority of RNA 
determinations have been conducted using ethidium bromide as the fluorochrome. In recent years, however, newer fluorochurmes, such as thiazole orange (Berdalet \& Dortch 1991), which have greater specificity and fluorescence yield have been developed and these fluorochromes should provide for greater sensitivity in RNA quantification. We combined previously existing techniques to extract and quantify both DNA and RNA from sonicated cellular extracts. The method is simple, rapid, and reproducible. Because of the simplicity (i.e sonication and fluorometry), total nucleic acid recovery should be high due to the absence of organic extraction and precipitation steps.

RNA, DNA, and protein content determined in this study agree with values determined in other studies. We report an average bacterial DNA content of $5.75 \mathrm{fg}$ while Paul and co-workers (Paul \& Myers 1982, Paul \& Carlson 1984, Paul et al. 1985, Boehme et al. 1993) have consistently reported a bacterial genome size of approximately $5.5 \mathrm{fg}$ DNA cell ${ }^{-1}$. Our value of average RNA content falls within ranges reported in other studies. Lee \& Kemp (1994) recently reported bacterial RNA content between 1.6 and $5.4 \mathrm{fg} \mathrm{cell}$ - $^{-1}$ while Simon \& Azam (1989) calculated RNA contents between 1.9 and $9.5 \mathrm{fg} \mathrm{cell}^{-1}$. Our slightly higher values may be due, in part, to the more direct quantification method that we used. Protein content per cell was similar to that which Simon \& Azam (1989) measured for marine bacteria in the biovolume range of 0.05 to $0.4 \mathrm{\mu m}^{3}$ Simon \& Azam (1989) used high-performance liquid chromatography (HPLC) determination of amino acid residues from acid hydrolyzed bacteria for quantification of protein content for bacteria growing in seawater cultures. Protein concentration determined by the BCA assay is sensitive to the specific protein used as standard. For determination of protein in phytoplankton samples, for example, using BSA as standard may result in as much as a $30 \%$ underestimation of protein content relative to the use ribulose-1,5-diphosphate carboxylase (RuDPCase), an abundant protein in autotrophic organisms (Nguyen \& Harvey 1994). Comparable results between the definitive yet labor intensive HPLC determination (Simon \& Azam 1989) versus our simple $\overline{B C} A$ determination of protein in bacteriai size particles suggests that there is not a gross underestimation of protein content due to our use of BSA as a standard protein, or that such a bias is within our sample to sample error. We know of no other measure of protein content specifically for marine bacterioplankton with which to compare our resuits.

Biochemical measures of bacterial activity and growth rate have the advantage of not requiring an incubation period which may introduce bottle effects and changes in community structure. Biochemical measures also do not rely on the ability of the target organisms to take up and incorporate an exogenous substrate (e.g. the presence of thymidine kinase requircd for thymidine incorporation; Jeffrey \& Paul 1990). Interest in determining RNA:DNA ratios in environmental samples has received significant attention in recent years. Much of this attention may be traced to the wide use of $16 \mathrm{~S}$ rRNA probes and the report by DeLong et al. (1989) demonstrating that both cellular rRNA content and RNA:DNA ratios were significantly correlated with growth rates of Escherichia coli. Early reports suggested that taxon specific measures of RNA:DNA ratios are correlated with growth rates. Kerkhof \& Ward (1993) reported that RNA content decreased with decreasing growth rate for Pseudomonas stutzeri Zobell, even at very long generation times such as those suspected to be found in oligotrophic waters. Kemp et al. (1993) examined 4 marine bacterial isolates at growth rates comparable to those found in the environment. They reported that RNA:DNA ratios were closely related to growth rate for each isolate but that the relationship became less obvious when the individual isolates were combined to create a mixed community. To investigate whether this relationship is maintained in heterogeneous bacterial populations found in the environment, we have determined RNA: DNA in natural assemblages of microorganisms collected from a wide variety of locations in the Northern Gulf of Mexico and along the southeastern coast of the Florida peninsula. These diverse environments ranged from oligotrophic waters to extreme-ly productive coral surface microlayers. Traditional measures of heterotrophic activity ranged over 3 orders of magnitude, from $10^{-22}$ to $10^{-19} \mathrm{~mol}$ cell $\mathrm{l}^{-1} \mathrm{~h}^{-1}$ for thymidine incorporation and from $10^{-21}$ to $10^{-18} \mathrm{~mol} \mathrm{cell}{ }^{-1} \mathrm{~h}^{-1}$ for leucine incorporation. These values are equivalent to estimated values for $\mu$ ranging from 0.0005 to 0.5 (Hoch \& Kirchman 1993). RNA:DNA ratios from these samples varied much less with respect to heterotrophic activity, ranging from approximately 0.5 to 3 with an average of $1.42 \pm 0.57$ for samples collected from the bacterial size fraction $(<0.8 \mu \mathrm{m})$. Correlation coefficients between RNA:DNA ratios and rates of thymidine and leucine incorporation demonstrated poor relationships among these paldneters (Fiy. 3). Furitier analysis found no distinction between offshore, onshore, and estuarine waters. During the cruise aboard the RV 'Bellows' in May 1992 we followed RNA:DNA ratios during outgoing tidal cycles at 4 estuaries in NW Florida and could not detect a pattern in RNA:DNA ratios even as bacterial productivity doubled.

There are only limited data available with which to compare the RNA:DNA ratios determined in this study. Using the fluorochromes ethidium homodimer and Hoechst 33258, Mordy \& Carlson (1991) reported RNA 
DNA ratios very similar to those reported here. They examined RNA:DNA ratios in the $<1 \mu \mathrm{m}$ size fraction in waters collected in a depth profile off the California coast and reported ratios ranging from 1 to 4 . It is more difficult to compare values determined in other studies owing to the differences by which RNA:DNA ratios were determined. In general, RNA:DNA ratios measured for cultures grown at environmentally relevant rates $\left(0.01\right.$ to $\left.0.001 \mathrm{~h}^{-1}\right)$ were comparable to those measured in the heterogeneous samples reported here, i.e. ratios between 1 and 4 (Kemp et al. 1993, Kerkhof \& Ward 1993)

Kemp et al. (1994) reported results comparing thymidine and leucine incorporation rates with RNA:DNA ratios in samples collected from 3 transects near Cape Hatteras, North Carolina, USA. RNA:DNA ratios were determined using oligonucleotide rRNA probes. That study also reported a lack of correlation between bacterial activity and RNA:DNA ratios very similar to that reported here when nucleic acid fluorochromes were used to quantify nucleic acids.

Lee \& Kemp (1994) combined multiple rRNA probes and fluorometry to estimate bacterial RNA and DNA content in winter and summer samples collected off of Long Island, New York, USA. They reported an inverse relationship between RNA content and temperature. No consistent relationship was reported, however, between rates of thymidine incorporation and RNA content. We observed no relationships between temperature and macromolecular content $\left(R^{2}=-0.21\right)$. Difference in sample size and locations could contribute to these apparent differences. While our data set was much larger, all samples were collected in subtropical and temperate locations where surface waters were predominately between 20 and $28^{\circ} \mathrm{C}$. Hoch \& Kirchman (1993) reported that bacterial growth rates in the Delaware Estuary correlated with temperature only at temperatures below $12^{\circ} \mathrm{C}$. In locations with small temperature fluctuations, other factors such as community structure and exposure to other stresses such as ultraviolet radiation (Herndl et al. 1993, Jeffrey unpubl. data) may strongly influence bacterial activity.

While RNA:DNA ratios measured do not appear to be related to bacterial activity in the environment (Fig. 3), RNA content was highly correlated with measures of bacterial biomass. The correlation coefficient determined between $\mu \mathrm{g}$ RNA $l^{-1}$ and $\mu \mathrm{g}$ DNA ${ }^{-1}$ was 0.84 (data not shown) while the correlation between $\mu \mathrm{g} \mathrm{RNA} \mathrm{I}^{-1}$ and bacterial cells $\mathrm{l}^{-1}$ was 0.769 (Fig. 4). This further supports the results that RNA content in bacteria in the environment is relatively constant and does not vary to the magnitude that other measures of microbial activity might.

The results from the environmental samples are in direct contrast with results determined for pure bacte- rial cultures in laboratory experiments. Early studies with strains of Escherichia coli and Salmonella typhimurium and more recent studies with marine bacterial isolates have all reported that RNA:DNA ratios are proportional to growth rates (Neidhardt \& Magasanik 1959, Kjeldgaard \& Kurland 1963, Maaløe \& Kjeldgaard 1966, Rosset et al. 1966, Kemp et al. 1993, Kerkhof \& Ward 1993) and that bacteria tend to contain a ribosomal complement in direct proportion to growth rate and protein synthesis demands (Maaløe \& Kjeldgaard 1966). RNA degradation has been thought to be a virtually universal response to starvation in bacteria, and starving bacteria use RNA as an endogenous metabolism substrate (Dagley \& Sykes 1957. Jacobson \& Gillespie 1968, Thomas \& Batt 1969, Dawes \& Large 1970, Boylen \& Mulks 1978 among many others). Contrasting results have been reported for marine bacteria. Amy et al. (1983) reported that the RNA content of a marine Vibrio sp. increased linearly after the first week of starvation until it was constant after 6 wk. It was postulated that this RNA was nonfunctional during the starvation process but was a reserve waiting for favorable environmental conditions or was present as a result of the absence of cellular regulation

Kemp et al. (1993) suggested that cellular RNA content was likely to be useful for estimating growth rates for marine bacterial assemblages but that the most success might be had when applying this methodology to the level of individual species. Our results support this statement. Relationships reported for limited sample sizes seem to deteriorate when large samples are analyzed. At the species level, or level at which organisms are clustered via 16S rRNA analysis, measures of RNA:DNA ratios might be indicative of growth rates in the environment. The use of specifically targeted $16 \mathrm{~S}$ rRNA probes may hold the potential for the most success because of the specificity inherent in the design of these probes. This could prove to be a powerful tool in examining specific activity of members of a heterogeneous microbial community (Lee et al. 1993). We must conclude, however, that, at the population level, the ratio of RNA:DNA cannot be used as an indicator of growth rates or activity in heterogeneous marine bacterioplankton.

Acknowledgements. We thank the captains and crews of the research vessels 'Bellows', 'Gyre', and 'Peter W. Anderson' for assistance in field sampling. We thank Kevin Dillon, Jed Campbell, Jeff Morin, and Leslie Cole for assistance in data collection and analysis. We thank Richard Snyder for comments on an earlier version of this manuscript. This work was supported in parts by shiptime awards from the Florida Institute of Oceanography to W.H.J., National Oceanic and Atmospheric Administration's National Undersea Research Center at the University of North Carolina at Wilmington NOAA contract UNCW9204S, and U.S. Environmental Pro- 
tection Agency Cooperative Agreement CR 818676-01-0 through the Gulf Breeze Environmental Research Laboratory to W.H.J.

\section{LITERATURE CITED}

Amy PS, Pauling C, Morita RY (1983) Starvation-survival processes of a marine Vibrio. Appl Environ Microbiol 45: $1041-1048$

Berdalet E, Dortch Q (1991) New double staining technique for RNA and DNA measurement in marine phytoplankton. Mar Ecol Prog Ser 73:295-305

Boehme J, Frischer ME, Jiang SC, Kellogg CA, Pichard S, Rose JB, Steinway C, Paul JH (1993) Viruses, bacterioplankton, and phytoplankton in the southeastern Gulf of Mexico: distribution and contribution to oceanic DNA pools. Mar Ecol Prog Ser 97:1-10

Boylen CW, Mulks MH (1978) The survival of coryneform bacteria during periods of prolonged nutrient starvation. J Gen Microbiol 105:323-334

Buckley IJ, Lough RG (1987) Recent growth, biochemical composition, and prey field of larval haddock (Melanogrammus aeglefinus) and Atlantic cod (Gadus morhua) on Georges Bank. Can J Fish Aquat Sci 44:14-25

Bulow FJ (1987) RNA-DNA ratios as indicators of growth in fish: a review. In: Summerfelt RC. Hall GE (eds) The age and growth of fish. Iowa State Univ Press, Ames, p 45-64

Chin-Leo G, Kirchman DL (1988) Estimating bacterial production in marine waters from the simultaneous incorporation of thymidine and leucine. Appl Environ Microbiol $54: 1934-1939$

Dagley S, Sykes J (1957) Effect of starvation upon the constitution of bacteria. Nature 179:1249-1250

Dawes EA, Large PJ (1970) Effect of starvation on the viability and cellular constituents of Zymomonas anaerobia and Zymomonas mobilis. J Gen Microbiol 60:31-42

Delong EF, Wickman GS, Pace NR (1989) Phylogenetic stains: ribosomal RNA-based probes for the identification of single cells. Science 243:1360-1363

Dortch QF, Clayton JR, Thoreson SS, Ahmed SI (1985) Nitrogen storage and the use of biochemical indices to assess nitrogen deficiency and growth rate in natural plankton populations. J Mar Res 43:437-464.

Findley RH, King GM, Watling L (1989) Efficacy of phospholipid analysis in determining microbial biomass in sediments. Appl Environ Microbiol 55:2888-2893

Fuhrman JA, Azam F (1982) Thymidine incorporation as a measure of heterotrophic bacterioplankton production in marine surface waters: evaluation and field results. Mar Biol 66:109-120

Herndl GJ, Muller-NikJas G, Frick J (1993) Major role of ultraviolet-B in controlling bacterioplankton growth in the surface layer of the ocean. Nature 361:717-719

Hobbie JE, Daley KJ, Jasper S (1977) Use of nuclepore filters for counting bacteria by fluorescence microscopy. Appl Environ Microbiol 33:1225-1228

Hoch MP, Kirchman DL (1993) Seasonal and inter-annual variability in bacterial production and biomass in a temperate estuary. Mar Ecol Prog Ser 98:283-295

Jacobson A, Gillespie D (1968) Metabolic events occurring during recovery from prolonged glucose starvation in Escherichia coli. J Bacteriol 95:1.030-1039

Jeffrey WH. Paul JH (1986a) The activity of attached and freeliving Vibrio sp. as measured by thymidine incorporation, p-iodonitrotetrazolium reduction, and ATP/DNA ratios. Appl Environ Microbiol 51:150-156
Jeffrey WH, Paul JH (1986b) Activity measurements of planktonic microbial and microfouling communities in a eutrophic estuary. Appl Environ Microbiol 51:157-162

Jeftrey WH, Paul JH (1990) Thymidine uptake, thymidine incorporation, and thymidine kinase activity in marine bacterium isolates. Appl Environ Microbiol 56:1367-1372

Karl DM (1982) Selected nucleic acid precursors in studies of aquatic microbial ecology. Appl Environ Microbiol 44: $891-902$

Karl DM (1993) Total microbial biomass estimation derived from the measurement of particulate adenosine-5'triphosphate. In: Kemp PF, Sherr BF, Sherr EB, Cole JJ (eds) Handbook of methods in aquatic microbial ecology. Lewis Publishers, Boca Raton, p 359-367

Karl DM, Holm-Hansen O (1978) Methodology and measurement of adenylate energy charge ratios in environmental samples. Mar Biol 48:185-197

Kemp PF, Kerkhof L, Dunn M (1994) Distribution of rRNA content, bacterial activity, and bacterial abundance across the continental shelf at Cape Hatteras, USA. Abstract 012L-2. EOS 75:59

Kemp PF, Lee S, LaRoche $J(1993)$ Estimating the growth rate of slowly growing marine bacteria from RNA content. Appl Environ Microbiol 59:2594-2601

Kerkhof L, Ward BB (1993) Comparison of nucleic acid hybridization and fluorometry for measurement of the relationship between RNA/DNA ratio and growth rate in a marine bacterium. Appl Environ Microbiol 59: 1303-1309

Kirchman DL, K'Nees E, Hodson R (1985) Leucine incorporation and its potential as a measure of protein synthesis by bacteria in natural aquatic systems. Appl Environ Microbiol 49:599-607

Kjeldgaard NO, Kurland CG (1963) The distribution of soluble and ribosomal RNA as a function of growth rate. J Molec Biol 6:341-348

LaRock P, Lauer R, Schwartz J, Watanabe K, Weisenburg D (1979) Microbial biomass and activity in an anoxic, hypersaline basin. Appl Environ Microbiol 37:466-470

Lee S, Kemp PF (1994) Single-cell RNA content of natural marine planktonic bacteria measured by hybridization with multiple 16S rRNA-targeted fluorescent probes. Limnol Oceanogr 39:869-879

Lee S, Malone C, Kemp PF (1993) Use of multiple 16 S rRNAtargeted fluorescent probes to increase signal strength and measure cellular RNA from natural planktonic bacteria. Mar Ecol Prog Ser 101:193-201

Maaløe O. Kjeldgaard NO (1966) Control of macromolecular synthesıs. WA Benjamin, Inc., New York

Mordy CW, Carlson DJ (1991) An evaluation of fluorescence techniques for measuring DNA and RNA in marine microorganisms. Mar Ecol Prog Ser 73:283-293

Neidhardt F, Magasanik B (1959) Studies on the role of ribonucleic acid in the growth of bacteria. Biochim Biophys Acta 42:99-116

Nguyen RT, Harvey HR (1994) A rapid micro-scale method for the extraction and analysis of protein in marine samples. Mar Chem 45:1-14

Paul JH, Carlson D (1984) Genetic material in the marine environment implication for bacterial DNA. Limnol Oceanogr 29:1091-1097

Paul JH, Jeffrey WH, DeFlaun MF (1985) Particulate DNA in subtropical oceanic and estuarine planktonic environments. Mar Biol 90:95-101

Paul JH, Myers B (1982) Fluorometric determination of DNA in aquatic microorganisms by use of. Hoechst 33258. Appl Environ Microbiol 43:1393-1399 
Porter KG, Feig YS (1980) The use of DAPI for identifying and counting aquatic microflora. Limnol Oceanogr 25:943-948

Rosset R, Julien J, Monier R (1966) Ribonucleic acid composition of bacteria as a function of growth rate. J Molec Biol $18: 308-320$

Sambrook J, Fritsch EF, Manuatis T (1989) Molecular cloning a laboratory manual. Cold Spring Harbor Laboratory Press, Cold Spring Harbor, NY

Simon M, Azam F (1989) Protein content and protein synthesis rates of planktonic marine bacteria. Mar Ecol Prog Ser 51:201-213

Smith PK, Krohn RI, Hermanson GT, Mallia AK, Gartner FH,

Responsible Subject Editor: J. T. Hollhbaugh, Tiburon, California, USA
Provenzano MD, Fujimoto EK, Goeke NM, Olson BJ, Klenk DC (1985) Measurement of protein using bicinchoninic acid. Analyt Biochem 150:76-85

Suttcliffe WH (1970) Relationship between growth rate and ribonucleic acid concentration in some invertebrates. J Fish Res Bd Can 27:606-609

Thomas TD, Batt RD (1969) Degradation of cell constituents by starved Streptococcus lactis in relation to survival. J Gen Microbiol 58:363-369

Thoreson SS, Clayton JR, Dortch QF, Ahmed SI (1983) A rapid technique for the determination of RNA and DNA in marine phytoplankton. J Plankton Res 5:253-261

Manuscript first received: September 28, 1995

Revised version accepted: December 28, 1995 